\title{
Psychological Motives and Political Orientation-The Left, the Right, and the Rigid: Comment on Jost et al. (2003)
}

\author{
Jeff Greenberg \\ University of Arizona
}

\author{
Eva Jonas \\ LudwigMaximilians-Universität München
}

\begin{abstract}
Presenting an impressive model based on a large body of evidence, J. T. Jost, J. Glaser, A.W. Kruglanski, and F. J. Sulloway (2003) proposed that political conservatism uniquely serves epistemic, existential, and ideological needs driven by fears and uncertainties. The authors offer an alternative view based on conceptual considerations, historical events, features of communist ideology and practice, and additional social science research not reviewed by Jost et al. (2003). First, the authors take issue with Jost et al.'s (2003) description of the two core components of political conservatism. Second, they propose that the motives in the model are equally well served by rigid adherence to any extreme ideology regardless of whether it is right wing or left wing.
\end{abstract}

There is much to admire about Jost, Glaser, Kruglanski, and Sulloway's (2003) article on political conservatism. Their ambitious effort to clarify the psychological forces that contribute to political conservatism is important and provocative. The idea of motivated social cognition, that beliefs and attitudes are greatly influenced by motivation, has been advocated by many influential students of human nature (e.g., Dostoyevsky, 1880/1956; Freud, 1933/1965; Shakespeare, 1599/1968; Swift, 1714/1971). This idea has also been a cornerstone of many theories in social psychology (e.g., Festinger, 1957; Greenwald, 1980; Heider, 1958; Jost, Burgess, \& Mosso, 2001; Katz, 1960; Kruglanski, 1980; Solomon, Greenberg, \& Pyszczynski, 1991; Tesser, 1988) and has been supported amply by research (see, e.g., Dunning, 1999; Kunda, 1990; Pyszczynski \& Greenberg, 1987). Jost et al. (2003) explored the motives that contribute to political conservatism by reviewing a vast range of evidence and attempting to integrate a broad range of theoretical perspectives into a cogent model. The result is a very valuable contribution to the psychological study of political orientation.

As with any large-scale review, one could of course quibble about aspects of the authors' selection, interpretation, or statistical treatment of the empirical evidence. However, we would rather, in this limited space, focus on the big picture and suggest some issues that warrant further consideration. The big questions that their article addressed were, What is political conservatism? and What are the psychological motives that contribute to it? The authors provided interesting answers to these very difficult questions, but we would like to point out some problems with their answers.

Jeff Greenberg, Department of Psychology, University of Arizona; Eva Jonas, Department Psychologie, LudwigMaximilians-Universität München, Munich, Germany.

The coauthors' contributions to this article were equal. We thank Jamie Arndt, Klaus Heine, and Dieter Frey for their feedback on an earlier version.

Correspondence concerning this article should be addressed to Jeff Greenberg, Department of Psychology, University of Arizona, P.O. Box 210068, Tucson, Arizona 85721-0068. E-mail: jeff@u.arizona.edu
Jost et al.'s (2003) model proposes that advocacy of political conservatism is in large part a consequence of epistemic, existential, and ideological needs stemming from the desire to reduce uncertainties and fears. This view is akin to what Tetlock (1989) has referred to as the rigidity-of-the-right hypothesis, the idea that a conservative political orientation is uniquely associated with a cluster of concepts such as dogmatism, authoritarianism, and intolerance. Although the evidentiary base reviewed by Jost et al. (2003) does seem to suggest that a small amount of variance in conservatism can be accounted for by these motives (given the size of the reported correlations), we propose that such motives actually are served just as well by left-wing political orientations as by right-wing ones. In our view, the fear-and uncertainty-driven motives ably presented by Jost et al. (2003) contribute to ideological rigidity independently of whether the ideology is right-wing or left-wing. Our alternative position is based on a consideration of conceptual points, historical evidence, and some social science research not reviewed by Jost et al. (2003).

\section{What Is Political Conservatism?}

Jost et al. (2003) acknowledged the complexity of defining political conservatism because the specific attitudes and beliefs associated with it vary over time and place. Of course, human politics embodies much more diversity than the categories conservative versus liberal/socialist or right-wing versus left-wing suggest. For example, the categories liberal and conservative mean quite different sets of political attitudes in the United States than they do in European countries. However, assume for the moment that one can simplify the field of political beliefs using these types of labels. Within this approach, Jost et al. (2003) argued that the core of conservatism consists of resistance to change and a tolerance for inequality. Given the dictionary definition of conservatism and the policy record of American conservative politicians regarding minorities and the poor, these seem like reasonable core components. However, the centrality of these components runs into trouble very quickly when we consider real-world examples of political conservatism. 


\section{Resistance to Change Is Futile as a Core Component of Conservatism}

In the United States, political conservatives are constantly clamoring for change. Indeed, the conservative American's all-time favorite politician, Ronald Reagan, ran for president on a platform of change and did in fact change many things once in power. American conservatives claim that they want the government off their backs. They usually argue for less central control of government, less consumer safety, environmental, and weapons regulation, and less taxation. Indeed, many of them would argue that the core of conservatism is the desire for individual freedom. Conservative talk show hosts such as Rush Limbaugh and Michael Savage paint liberals as antifreedom advocates of "political correctness" and "big government." This conservative banner of freedom is quite misleading however, because in other very private domains, such as drug use, sexual and artistic expression and diversity, and children's and women's rights, conservatives generally argue for more restriction of freedom. In all of these domains, conservatives do want change, be it in the direction of more freedom or less. Indeed, the Religious Right, a potent conservative movement, seems to want change to the point of making Christianity the explicit basis of all government policy.

Conservatives are also currently on the march for change in many other countries, such as Great Britain, the Netherlands, and France. In the twentieth century, two of history's most horrifying conservative movements, Hitler's Nazism and Mussolini's fascism, gained power specifically because their leaders promised change. Jost et al. (2003) admitted that there is a "conservative paradox" (p. 342) of right-wing revolutionaries-but, quoting Muller (2001), they argued that it is more "an imaginatively transfigured conception of the past with which to criticize the present" (p. 2625).

From our point of view, this is an unsatisfactory solution. All political movements borrow from the past in some way. At the very least, leftists rely on the long-dead Karl Marx, and often on a myth of prehistoric egalitarian communalism. Even when rightwing movements do refer to values of the past, they are still seeking change in the present, and when successful, they often implement unprecedented new policies. For example, although Hitler sometimes referred to a mythic German past portrayed in Wagner's operas, his Nazi movement and regime bore little if any resemblance to that or any other past German society. In addition, some conservative movements even lack the pretense of harking back to a nation's past. Consider the democratic and pro-capitalism reforms in countries of the former Soviet Union. In those countries the past has been clearly communist, yet the reforms have reflected what can be described as features of Western conservatism (i.e., more power to the private market, less egalitarianism, and more application of equity principles).

Thus, it is clear from records of history and current political events that conservatives often want change. It is even clearer from these sources that left-wing governments often, in fact typically, are highly resistant to change. The former Soviet Union and the countries that were under its influence were notoriously repressive and harsh regarding dissent, as The People's Republic of China has continued to be. And how long has Castro been in power in Cuba? Although Jost et al. (2003) acknowledged some of these examples as "exceptions" (p. 343) and admitted that the figures involved might be considered politically conservative and that Stalin appeared "to have much in common with right-wing extremists" ( $p$. 343), they never explained how resistance to change can be retained as a core of political conservatism in light of these important examples. We don't think it can.

\section{Tolerance for Inequality as a Core of Political Conservatism}

The inequality idea seems to be on somewhat firmer ground, given the evidence provided by Jost et al. (2003), as well as the historical record. American conservatives typically put it differently; they argue for equality of opportunity and seem to favor an equity model. The conservative view seems to emphasize individual differences among people, such as differences in their efforts, talents, preferences, and willingness to undertake risks. Favoring the market system goes along with giving people freedom to choose what they want to consume, how much money they are willing to spend on certain products, and what kinds of jobs they want to perform. It also goes along with encouraging innovations, providing incentives for individual achievements through differences in income and disincentives for low productivity. Thus, in this sense, right-wing conservative philosophy does seem to entail greater tolerance for inequality of outcomes. However, a major argument of conservatives against liberalism is that liberals advocate inequality through advocacy of preferential treatment through affirmative action programs and social services. They, in contrast, want all people treated equally, that is, given ostensibly equal opportunities, regardless of gender or ethnicity. Of course, this reasoning is based on the conservative tendency in the United States to deny the reality of discrimination, which, given the empirical evidence, can only be viewed as ignorance or another product of motivated social cognition. One can thus view this conservative reasoning as a smokescreen to hide a preference for inequality.

However, the historical record seems to suggest that left-wing governments often show remarkable tolerance for inequality as well. Even though the communist philosophy proclaims social equality, it seems many communist countries developed their own hierarchies of privilege in such domains as housing, recreation, health care, food, and other consumer goods (e.g., Leonhard, 1957, 1986; Olson, 2000; Schoensee \& Lederer, 1991). Thus, communist authorities have established strong barriers between themselves and the general public. They also seem to be quite tolerant of unequal treatment of those who do not espouse the party line. The evidence suggests that millions of people in the former Soviet Union were killed or institutionalized because of their political views (see, e.g., Courtois, Werth, Paczkowski, Bartosek, \& Margolin, 1999; Leonhard, 1986). Similar unequal treatment of those with different opinions has been documented in China and other nations ruled by left-wing governments (see, e.g., Amnesty International, 2001; Wright, 2001).

Perhaps part of the reason high resistance to change and severe violations of egalitarianism occur so consistently in extremely left-wing countries is because the needs to reduce uncertainty and fear drive those in power to defend their ideology and squash dissent despite the inherent contradiction with the principles associated with the ideology. When this process is combined with an ideology that mandates tight control over economic behavior, the 
common result seems to be totalitarianism, which involves an emphasis on resistance to change, the use of fear to enforce control, and a minimization of uncertainties and individual freedoms (cf. Orwell, 1946).

\section{Do Certain Psychological Motives Contribute Uniquely to Political Conservatism?}

Consistent with their conceptualization of the core components of political conservatism as resistance to change and tolerance for inequality, the main thrust of Jost et al.'s (2003) analysis is that political conservatives tend toward rigidity and dogmatism and are driven by fears inspired in part by their view of the world as a dangerous place and of people as capable of evil. More specifically, they stated that

a number of different epistemic motives (dogmatism-intolerance of ambiguity; cognitive complexity; closed-mindedness; uncertainty avoidance; needs for order, structure, and closure), existential motives (self-esteem, terror management, fear, threat, anger, and pessimism), and ideological motives (socioeconomic self-interest, group dominance, and system justification) are all related to the expression of political conservatism. (Jost et al., 2003, p. 351)

They went on to say that these motives all "originate in psychological attempts to manage uncertainty and fear" and "in turn, are inherently related to the two core aspects of conservative thought mentioned earlier-resistance to change and the endorsement of inequality" (Jost et al., 2003, p. 351).

We think it is a substantial achievement to combine and integrate different social-cognitive motives and derive convergent predictions. We also agree that ideological beliefs can help to reduce uncertainty, fears, anxiety and "mitigate feelings of threat and worthlessness" (Jost et al., 2003, p. 351). However, we do not agree that these motives only characterize political conservatives (in the sense of people holding right-wing political attitudes) as Jost et al. (2003) suggested. We are not convinced by the authors' attempt to show that the "specific array of epistemic, existential, and ideological motives ... uniquely [italics added] characterizes political conservatism as a system of interrelated beliefs" (Jost et al., 2003, p. 342) and think this approach is too narrow. We agree that these motives are driven by desires to reduce fear, anxiety, and uncertainty, but we propose that left-wing ideologies serve these motives just as well as right-wing ones.

In fact, the majority of the motivational theories Jost et al. (2003) used to formulate their hypotheses seem to suggest that this would be true. Need for closure, terror management, uncertainty reduction, prevention focus, and system justification are all best served by embracing and rigidly adhering to and defending whatever the prevailing ideology is in one's sociocultural environment. Social dominance seems to be the one motive that may be more compatible with particular ideological content. However, even in this case, embracing the prevailing ideology, even if it ostensibly advocates a form of egalitarianism, may be the best way pragmatically to serve social dominance needs because doing so aligns one with the powers that be.

\section{Is Political Conservatism Particularly Well Suited to Reducing Fear and Uncertainty?}

The notion that conservatives are more guided by fear and uncertainty than liberals runs counter to a variety of incarnations of right- and left-wing ideology around the world; even within the United States, there are some clear exceptions to Jost et al.'s (2003) characterization of political conservatism. Although there is a long tradition to the idea that liberals view people as good and society as corrupting whereas conservatives view people as capable of evil and society as necessary to save people from themselves (see, e.g., the discussion in Becker, 1975), there is an interesting reversal of this idea in contemporary American politics. One common criticism conservatives voice against liberals is that they do not trust people to make their own decisions; they complain that liberals always want federal control over local issues and are always trying to mandate people's behavior, be it in terms of wearing seatbelts and motorcycle helmets, environmental regulation, antismoking and antidiscrimination laws, gun control, taxation, and so forth. Indeed, Mehrabian (1996) found that on a dimension ranging from libertarianism to totalitarianism, conservatives were closer to the libertarian pole than were moderates or liberals.

More generally, in favoring a capitalistic system, economic liberty, and a free-market economy, conservatives seem to be quite tolerant of uncertainties, whereas the centrally planned economic system favored by communists suggests that communist systems actually may better serve to reduce many uncertainties. In understanding market competition as a discovery procedure for innovations with uncertain and unplannable outcomes (Hayek, 1975), conservatives reveal a remarkable amount of trust that good things can come out of uncertainties. Demanding individual freedom in so many different areas actually does not support the idea that pro-capitalist conservatives are motivated to reduce uncertainty because allowing individuals to choose and to be free to do whatever they want and think is best-and thus rise and fall on the basis of the consequences of their decisions and efforts-clearly increases uncertainty. Perhaps the differences among conservatives, liberals, and communists have nothing to do with levels of concern about threats, uncertainties, and fears but rather reflect different ways of coping with these negative aspects of life, or perhaps they reflect a focus on different types of threats and uncertainties. $^{1}$

\section{Empirical Findings From Communist Countries}

Jost et al. (2003) rightly noted that the large majority of the available social science research supports a link between conservatism and dogmatism-like concepts. However, with just a couple of exceptions from politically complex post-Soviet Poland, the samples from the studies they reviewed are from nations in which extreme left-wing governments clearly are not in place. How would hard-line communists or Marxists from the former Soviet Union or from China and Cuba or leftist "rebels" from South American countries have fared on measures of dogmatism? Tet-

\footnotetext{
${ }^{1}$ Two brief examples from the terror management literature are particularly relevant here. Dechesne, Janssen, and van Knippenberg (2000) found that Dutch participants who were both high and low on the need for closure engaged in defense in response to mortality salience, but the defenses they used were quite different. Lieberman, Arndt, Personius, and Cook (2001), using American participants, recently found that mortality salience encouraged both support for hate crimes legislation (a liberal position) and leniency toward a bigot (a more conservative tendency).
} 
lock (1989) similarly pointed out that a problem with interpreting the empirical psychological research on political attitudes and their correlates arises from the fact that

the far right has typically included advocates of racial segregation, supporters of major restrictions on civil liberties, and radical militarists. By contrast, the far left has rarely included Marxists or doctrinaire socialists. Indeed, the far left has often not extended beyond advocates of welfare state liberalism and social democracy. (p. 132)

Although there is less empirical research on such left-wing extremism, the existing evidence from the historical record nevertheless suggests that rigid, extreme, and dogmatic adherence is characteristic of proponents of all types of extreme political ideologies, left-wing as well as right-wing. In describing "the hate, violent prejudices, and authoritarian obedience to the revolutionary party among the Russian revolutionaries in the late 19th century" (McFarland, Ageyev, \& Abalakina, 1993, p. 222), Dostoyevsky's (1872/1914) novel The Possessed is an example from literature of a portrayal of such left-wing dogmatism. Jost et al. (2003) themselves made the point that "future research-especially if conducted in traditionally socialist or communist societies in which adherence to the status quo is unconfounded with right-wing ideological orientation-would add significantly to knowledge about political conservatism as motivated social cognition" ( $\mathrm{p}$. 369). However, there actually is some pertinent research that they overlooked.

Jost et al. (2003) noted that

authoritarianism is often taken to be synonymous with conservatism, but Wilson, theorizing that conservatism is the general factor underlying all social attitudes (Wilson, 1973b; Wilson \& Patterson, 1968), contended that authoritarianism is but one manifestation of the more general factor of conservatism (Wilson, 1968). (p. 345)

They further outlined that Altemeyer's (1981) right-wing authoritarianism is characterized by (a) "a high degree of submission to the authorities who are perceived to be established and legitimate," (b) "a general aggressiveness, directed against various persons, which is perceived to be sanctioned by established authorities," and (c) "a high degree of adherence to the social conventions which are perceived to be endorsed by society" (Altemeyer, 1981, p. 148, as cited in Jost et al., 2003, p. 345). It seems to us that this description applies well to people supporting left-wing communist ideology.

Some studies have examined authoritarianism in communist countries. ${ }^{2}$ For example, Larsen, Groberg, and Simmons (1993) found that in some former socialist societies, like Bulgaria and Hungary, respondents scored even higher on authoritarianism than did samples from the United States (Oregon) and Norway. Lederer and Kindervater (1995) compared authoritarianism among school children from East Germany (1990), West Germany (1992), and the Soviet Union (1991). They found that children from the Soviet Union scored the highest, followed by children from East Germany, with West German children's scores being the lowest. However, contradictory to this, McFarland, Ageyev, and Abalakina-Paap (1992), McFarland et al. (1993), and Altemeyer (1996) found that participants from the Soviet Union on average were less authoritarian than Americans from selected states.

More important are the studies comparing high- and lowauthoritarian people within one country. Altemeyer (1996) found that for samples from Moscow and different places in the United States authoritarian persons in both countries revealed similar nationalistic attitudes. Other studies (McFarland et al., 1992, 1993; McFarland, Ageyev, \& Djintcharadze, 1996) found that in 1989, 1991, and 1993, authoritarianism in Russia correlated positively with pro-communist beliefs and opposition to capitalism (although this relationship was a bit weaker in 1993), thereby illustrating that authoritarianism is not necessarily tied to the specific conservative ideologies found in the West. Because authoritarianism is tied to conventionalism, it can be expressed by supporting all kinds of different cultural norms. Thus, whereas Western authoritarianism was correlated with anti-communism, authoritarianism in Russia correlated with support of the communist party, belief in communist principles, and resisting change to capitalist and democratic reforms; thus, in the Soviet Union, left-wing orientation was correlated positively with authoritarianism.

In addition, these studies also support Altemeyer's (1996) conclusion that Russian authoritarians exhibited a lot of similarities with Western conservatives. Moreover, McFarland et al. (1992) suggested that

the authoritarian personality in the Soviet Union, although procommunist, was psychologically the same as Western authoritarianism... Both Soviet and Western authoritarianism have appeared to embrace a common conventionalism (including fears of dissidence, free thought, and personal liberty), authoritarian submission, and authoritarian aggression. (p. 1005)

In all cases, the intensified loyalty to cultural norms was "coupled with hostility directed toward the culture's deviants, malcontents, and enemies and with support for the use of force against those who are perceived as threats to the accepted order" (McFarland et al., 1992, p. 1008).

This evidence supports our point made earlier, that resistance to change is common among people holding left-wing political communist attitudes as well as among those holding right-wing political authoritarian attitudes. McFarland et al.'s (1992) findings also cast doubt on the idea that authoritarianism generally goes along with the endorsement of inequality. Although the authoritarian personalities in Russia were psychologically similar to those in the West, this was not the case regarding inequalities. Whereas in the American sample authoritarianism correlated negatively with egalitarianism and positively with individualism (e.g., on ideas that housing should be determined by one's ability to pay), in the Russian sample a positive correlation of authoritarianism with egalitarianism and a rejection of individualism was found (McFarland et al., 1992). To make things even more complicated, McFarland et al. (1993) found increased ethnocentrism, prejudice, and discriminating attitudes toward out-groups among authoritarian

\footnotetext{
${ }^{2}$ In studies on authoritarianism in communist countries some of the items of Altemeyer's Right Wing Authoritarianism Scale were modified. For example, a "statement about freedom of speech allowing people to advocate overthrowing the government was changed to say Soviet people must have the right to criticize the Communist Party and demand its resignation from power" (Altemeyer, 1996, p. 123). McFarland et al. (1992), for example, "substituted 'People should pay less attention to the Marxism-Leninism ...' for 'People should pay less attention to the Bible ...' and 'Capitalists and those who are out to destroy socialism ...' for 'Communists and those who are out to destroy religion ...'.' (p. 1005).
} 
persons in the Soviet Union. This suggests that in certain domains, communist attitudes can also go along with endorsement of inequality (see also McFarland, 1998, who showed that communist fundamentalism predicted discriminatory attitudes among Communist Party members). ${ }^{3}$

Jost et al. (2003) stated that "rigidity and closed-mindedness were consistently associated more with conservative thinking styles than with their alternatives" (p. 352). However, a study by Tetlock and Boettger (1989) about cognitive and rhetorical styles of Soviet politicians indicates otherwise. Those authors found that Soviet politicians advocating the introduction of market mechanisms into the Soviet economy tended to be more integratively complex than those advocating traditional communist positions, including the centrally planned economy. Thus, in the Soviet Union, those favoring capitalistic goals (which are features of Western conservatism) displayed more complex thinking than those who embraced more left-wing communist ideology.

In communist regimes there are also clear examples of government policies that fit features that, according to Jost et al. (2003), are connected to conservatism. They suggested that conservatives can be characterized by having a desire for order and stability, idealization of authority figures, adherence to preexisting social norms, acceptance of the death penalty, and advocation of severe punishments for criminals and massive police departments. However, evidence supports the notion that these correlates of conservatism in capitalist countries also apply to authoritarian people in communist systems and the systems themselves. For example, McFarland et al. (1992) found that Russian authoritarianism was connected with support for hard-line communist leaders. The state security organizations in socialist and communist countries, for instance, the "Stasi" (Staatssicherheit) in the former German Democratic Republic, which led to spying activities among citizens in all different areas of everyday life, provided vivid examples of massive police departments in countries ruled by left-wing governments. Aggression and hostility toward people who are different are considered features of authoritarianism. Of course, favoring of harsh punishment for criminals (including the death penalty) and favoring reduction of freedom of speech can be observed among supporters of any repressive regime-be it right-wing or left-wing communist. In addition, group-based dominance (ruling party class), submissive posture toward authorities, and system justification phenomena like defending the existing social system against instability, threat, and attack can also be observed in communist systems (perhaps especially so because they tend to take on a highly authoritarian, totalitarian character). McFarland et al. (1996) even found that "Russian, like American authoritarians, hold negative attitudes toward environmentalists, and toward those with AIDS. However, unlike American authoritarians, Russian authoritarians blame the economic system for homelessness and poverty" (p. 215).

\section{Right- Versus Left-Wing Attitudes and Ideological Rigidity as Orthogonal Dimensions}

In sum, we think that the motives elegantly integrated in Jost et al.'s (2003) model do not contribute specifically to political conservatism. Rather, from our point of view, they contribute to ideological rigidity and associated in-group favoritism, a syndrome that can be found readily among people around the world with right- or left-wing attitudes, with polarity to either the left or right depending primarily on the dominant ideology of the individual's culture. Even Americans who refer to themselves as liberals can become rigid defenders of their ideology, as the concept of political correctness suggests.

We are aware that theorists and researchers have already devoted a great deal of thought and research to attempting to understand the essential dimensions of political attitudes (for overviews, see, e.g., Duckitt, 2001; Tetlock, 1989). Our admittedly quick-fix solution, inspired in part by Duckitt (2001), Tetlock (1989), and Altemeyer (1996), is to suggest a framework consisting of one content dimension and one content-free dimension and view them as orthogonal. ${ }^{4}$ From this perspective, one dimension could be called right-left, referring to the content of ideology. Rightwingers favor a free-market economy, individual responsibility, genetic or will-based theories of individual differences, and equity principles. Left-wingers prefer a socialist or communist economic system, communal responsibility, social theories of individual differences, and equality principles. The content-free dimension could be called ideological rigidity, its pole varying from low to high to describe the strength of orientation toward an ideology. Those who are ideologically rigid closed-mindedly and unquestioningly cling to their ideology, seeing it as absolutely right and seeing alternatives as absolutely wrong. They are therefore biased against different others and live certain in their knowledge. Low-

\footnotetext{
${ }^{3}$ This body of research could help to clarify two sets of findings Jost et al. (2003) reported from studies in Eastern European countries. They mentioned that Golec (2001) found in two Polish samples that need for closure was negatively correlated with "economic conservatism, presumably because of Poland's traditionally socialist economy. . . . However, when she examined youth affiliates of various political parties ...the strongest ever associations between the (ideologically content-free) [Need for Closure Scale] and political conservatism were observed" (Jost et al., 2003, p. 360). McFarland et al. (1996) also found that although authoritarianism in Russia in 1993 was still connected with communism, it also predicted support for non-communist reactionary parties (see also Altemeyer's, 1996, observation that right-wing and left-wing authoritarianism can correlate and that people who have high scores on both reveal high hostility and dogmatism). Depending on the individual and the political climate, authoritarianism can predict support for both communist and right-wing parties

Jost et al. (2003) referred to findings from East Germany reported by Fay and Frese (2000) as supporting the notion that right-wing conservatism is associated with aversion to uncertainty and resistance to innovation. However, we think this is not justified. Fay and Frese observed that in East Germany it was unclear whether conservatism-authoritarianism was associated with a right-wing or a with a Marxist-socialistic political orientation. Therefore, Fay and Frese refrained from measuring conservatism by assessing right-wing political orientation and, instead, just assessed hostility toward foreigners and a preference for strong authority, strict rules, and punishment. Indeed, they pointed out that the Conservatism Scale was not applicable to their sample and that, to measure conservatism in East European countries, "assessing Marxist or socialist orientations is more appropriate" (Fay and Frese, 2000, p. 179).

${ }^{4}$ Duckitt (2001, p. 47), for example, summarized earlier work as suggesting two dimensions of political attitudes. One dimension involves authoritarianism/social conservatism/traditionalism/national strength/order versus liberalism/openness/freedom/tolerance. The second dimension involves economic conservatism/power distance/hierarchy/inequality versus egalitarianism/humanitarianism/social welfare/social concern.
} 
ideological rigidity people are open-minded and tolerant; they view their preferred ideology as a personal choice but are open to questioning it and willing to consider and acknowledge the possible virtues of alternative views. They are ideologically malleable and live with epistemic uncertainty.

We suggest that ideological rigidity has much in common with the related concepts of dogmatism and authoritarianism and that, in our framework, submissive, aggressive, and conventional authoritarian attitudes are equally likely among people holding political right-wing and left-wing attitudes. The historical record and research we have discussed strongly suggests that attitudes like believing in strong leaders and submission, preferring one's own in-group, ethnocentrism and nationalism, aggression against dissidents, and control with the help of police and military are common characteristics of people who subscribe to any extreme government or ideology, whether it is right-wing or left-wing.

Under this framework, hard-line communists would be viewed as left-wing and ideologically rigid. The American moderate conservative would then be viewed as right-wing but low in rigidity. Presumably, genuine liberals, to the extent they are characterized by open-mindedness and interest in diversity, would always be questioning of authorities and willing to consider alternative viewpoints; therefore, they would tend to be low in rigidity and relatively left-wing in capitalist countries but relatively right-wing in communist countries.

Of course, the phenomena falling under the label conservatism still warrant further psychological understanding. That said, we believe that prevailing cultural norms, socialization influences, and perhaps, certain genetic predispositions (see, e.g., Tesser, 1993), rather than the need to reduce fear and certainty, play the primary roles in determining whether people develop right- or left-wing political attitudes. However, if an individual has particularly strong needs to reduce fear and uncertainty, she or he would most likely grab on tightly to the prevailing ideology — whether oriented to the right or the left-unless, because of specific life circumstances or personality attributes, the prevailing ideology is not functioning to quell those concerns for that individual. In that case, the individual would grab on to a countercultural or deviant ideology and, if driven by fear and uncertainty, would most likely do so with the same zeal and rigidity.

One could argue that in the United States and most other capitalist nations there are not many advocates of the extreme left or much in the way of a coherent left-wing ideology and that therefore, as the research reviewed by Jost et al. (2003) suggests, it may very well be the case that in such nations, on average, right-wingers are more ideologically extreme and rigid. People looking for an extreme, coherent, noncomplex, and rigid political ideology simply may not be as attracted to the left-wing in places like the United States. However, in other parts of the world, it is a different story. Given the once vast influence of the Soviet Union, and that even vaster current proponent of communism, China, we think it makes more sense when looking at the global picture to view the right-wing versus the left-wing as one dimension and ideologically rigid versus ideologically open as a second, quite independent dimension.

We certainly agree with Jost et al. (2003) that it is important for social psychologists to devote more thought and research to clarifying psychological forces behind political attitudes and behavior, and we admire their effort to do so. However, as suggested recently by Redding (2001, see also 2002), psychological theorizing and research on political attitudes always run the risk of being guided by the motivated social cognition of the theorists and researchers on the basis of their own sociopolitical views. Although we are undoubtedly no less guilty of this than Jost et al. (2003), we hope that our contribution serves as a small counterweight toward balance and diversity in the application of motivated social cognition to understanding the determinants of political orientation.

\section{References}

Altemeyer, R. A. (1981). Right-wing authoritarianism. Winnipeg, Manitoba, Canada: University of Manitoba Press.

Altemeyer, R. A. (1996). The authoritarian specter. Cambridge, MA: Harvard University Press.

Amnesty International. (2001). Annual report. Retrieved June 20, 2002 from http://web.amnesty.org/web/ar2001.nsf/webasacountries/CHINA

Becker, E. (1975). Escape from evil. New York: Free Press.

Courtois, S., Werth, N., Paczkowski, A., Bartosek, K., \& Margolin, J.-L. (1999). The black book of communism: Crimes, terror, repression. Cambridge, MA: Harvard University Press.

Dechesne, M., Janssen, J., \& van Knippenberg, A. (2000). Derogation and distancing as terror management strategies: The moderating role of need for closure and permeability of group boundaries. Journal of Personality and Social Psychology, 79, 923-932.

Dostoyevsky, F. M. (1914). The possessed (C. Garnett, Trans.). London: William Heinemann. (Original work published 1872)

Dostoyevsky, F. M. (1956). The brothers Karamazov (C. Garnett, Trans.). New York: Dell. (Original work published 1880)

Duckitt, J. (2001). A dual-process cognitive-motivational theory of ideology and prejudice. In M. P. Zanna (Ed.), Advances in experimental social psychology (Vol. 33, pp. 41-113). San Diego, CA: Academic Press.

Dunning, D. (1999). A newer look: Motivated social cognition and the schematic representation of social concepts. Psychological Inquiry, 10, $1-11$.

Fay, D., \& Frese, M. (2000). Conservatives' approach to work: Less prepared for future work demands? Journal of Applied Social Psychology, 30, 171-195.

Festinger, L. (1957). A theory of cognitive dissonance. Stanford, CA: Stanford University Press.

Freud, S. (1965). New introductory lectures on psychoanalysis (J. Strachey, Trans.). Oxford, England: W. W. Norton. (Original work published 1933)

Greenwald, A. G. (1980). The totalitarian ego: Fabrication and revision of personal history. American Psychologist, 35, 603-618.

Golec, A. (2001, July). Need for cognitive closure and political conservatism: Studies on the nature of the relationship. Paper presented at the annual meeting of the International Society of Political Psychology, Cuernavaca, Mexico.

Hayek, F. A. von. (1975). The pretence of knowledge. American Economic Review, 79, 3-7.

Heider, F. (1958). The psychology of interpersonal relations. New York: Wiley.

Jost, J. T., Burgess, D., \& Mosso, C. (2001). Conflicts of legitimation among self, group, and system: The integrative potential of system justification theory. In J. T. Jost \& B. Major (Eds.), The psychology of legitimacy: Emerging perspectives on ideology, justice, and intergroup relations (pp. 363-388). New York: Cambridge University Press.

Jost, J. T., Glaser, J., Kruglanski, A. W., \& Sulloway, F. J. (2003). Political conservatism as motivated social cognition. Psychological Bulletin, 129, $339-375$. 
Katz, D. (1960). The functional approach to the study of attitudes. Public Opinion Quarterly, 24, 163-204.

Kruglanski, A. (1980). Lay epistemology process and contents. Psychological Review, 87, 70-87.

Kunda, Z. (1990). The case for motivated reasoning. Psychological Bulletin, 108, 480-498.

Larsen, K. S., Groberg, D. H., \& Simmons, D. D. (1993). Authoritarianism, perspectives on the environment, and work values among social science students in former socialist and western societies. Social Behavior and Personality, 21, 251-264.

Leonhard, W. (1957). Child of the revolution. London: Collins.

Leonhard, W. (1986). The Kremlin and the West. New York: Norton.

Lederer, G., \& Kindervater, A. (1995). Internationale Vergleiche [International comparisons]. In G. Lederer \& P. Schmidt (Eds.), Autoritarismus und Gesellschaft-Trendanalysen und vergleichende Jugenduntersuchungen 1945-1993. Opladen, Germany: Leske+Budrich.

Lieberman, J. D., Arndt, J., Personius, J., \& Cook, A. (2001). Vicarious annihilation: The effects of mortality salience on perceptions of hate crimes. Law and Human Behavior, 25, 547-566.

McFarland, S. (1998). Communism as religion. International Journal for the Psychology of Religion, 8, 33-48.

McFarland, S., Ageyev, V., \& Abalakina, M. (1993). The authoritarian personality in the U.S.A. and the U.S.S.R.: Comparative studies. In W. F. Stone, G. Lederer, \& R. Christie (Eds.), Strengths and weakness: The authoritarian personality today (pp. 199-225). New York: Springer-Verlag.

McFarland, S., Ageyev, V. S., \& Abalakina-Paap, M. A. (1992). Authoritarianism in the former Soviet Union. Journal of Personality and Social Psychology, 63, 1004-1010.

McFarland, S., Ageyev, V. S., \& Djintcharadze, N. (1996). Russian authoritarianism two years after communism. Personality and Social Psychology Bulletin, 22, 210-217.

Mehrabian, A. (1996). Relations among political attitudes, personality, and psychopathology assessed with new measures of libertarianism and conservatism. Basic and Applied Social Psychology, 18, 469-491.

Muller, J. Z. (2001). Conservatism: Historical aspects. In N. J. Smelser \& P. B. Baltes (Eds.), International encyclopedia of the social and behavioral sciences (pp. 2624-2628). Amsterdam: Elsevier.

Olson, M. (2000). Power and prosperity: Outgrowing communist and capitalist dictatorships. New York: Basic Books.
Orwell, G. (1946). Animal farm. New York: Harcourt Brace.

Pyszczynski, T., \& Greenberg, J. (1987). Toward an integration of cognitive and motivational perspectives on social inference: A biased hypothesis-testing model. In L. Berkowitz (Ed.), Advances in experimental social psychology (Vol. 20, pp. 297-340). Hillsdale, NJ: Erlbaum.

Redding, R. E. (2001). Sociopolitical diversity in psychology: The case for pluralism. American Psychologist, 56, 205-215.

Redding, R. E. (2002). Grappling with diverse conceptions of diversity. American Psychologist, 57, 300-301.

Schoensee, R., \& Lederer, G. (1991). The gentle revolution. Political Psychology, 12, 309-330.

Shakespeare, W. (1968). As you like it. New York: Dell. (Original work published 1599)

Solomon, S., Greenberg, J., \& Pyszczynski, T. (1991). A terror management theory of social behavior: The psychological functions of selfesteem and cultural worldviews. In M. P. Zanna (Ed.), Advances in experimental social psychology (Vol. 24, pp. 93-159). San Diego, CA: Academic Press.

Swift, J. (1971). Gulliver's travels. London: Oxford University Press. (Original work published 1714)

Tesser, A. (1988). Toward a self-evaluation maintenance model of social behavior. In L. Berkowitz (Ed.), Advances in experimental social psychology (Vol. 21, pp. 181-227). San Diego, CA: Academic Press.

Tesser, A. (1993). The importance of heritability in psychological research: The case of attitudes. Psychological Review, 100, 129-142.

Tetlock, P. E. (1989). Structure and function in political belief systems. In A. R. Pratkanis, S. J. Breckler, \& A. G. Greenwald (Eds.), Attitude structure and function (pp. 129-151). Hillsdale, NJ: Erlbaum.

Tetlock, P. E., \& Boettger, R. (1989). Cognitive and rhetorical styles of traditionalist and reformist Soviet politicians: A content analysis study. Political Psychology, 10, 209-232.

Wright, T. (2001). The perils of protest: State repression and student activism in China and Taiwan. Honolulu: University of Hawaii Press.

Received June 22, 2002

Revision received July 7, 2002

Accepted July 8, 2002

\section{E-Mail Notification of Your Latest Issue Online!}

Would you like to know when the next issue of your favorite APA journal will be available online? This service is now available to you. Sign up at http://watson.apa.org/ notify/ and you will be notified by e-mail when issues of interest to you become available! 